\title{
Methods of determining the reaction of sunflower genotypes to terminal bud attack by Sclerotinia sclerotiorum (Lib) De Bary
}

\author{
EH Achbani*, D Tourvieille de Labrouhe ${ }^{\star *}$, F Vear \\ INRA, Centre de Recherche Agronomique, Domaine de Mon Désir, F63039 Clermont-Ferrand Cedex 2, France
}

(Received 4 August 1993; accepted 31 January 1994)

\begin{abstract}
Summary - Possible methods to test the reaction of sunflower genotypes to terminal bud attack by Sclerotinia sclerotiorum were studied. Percentage attack in the field under natural conditions was taken as a basis for comparison of the different test methods, since it has been shown that genotype ranking according to reaction to natural attack is stable. Two tests gave results significantly correlated with those of natural attack. A test measuring mycelium extension along the young stem from an explant placed on the terminal bud gave a correlation of $r=0.554(n=20)$. An infection by ascospores after wounding a young leaf with a soldering iron gave a correlation of $r=0.444(n=20)$. These tests can be used in breeding programmes. The results of other tests on leaves and stems were not correlated with terminal bud attack, confirming that reaction of sunflowers to $S$ sclerotiorum depends on the plant part attacked.
\end{abstract}

\section{Sclerotinia sclerotiorum / sunflower / test / terminal bud / correlation}

Résumé - Méthodes d'études de la réaction du tournesol aux attaques du bourgeon terminal par Sclerotinia sclerotiorum. L'obtention d'hybrides de tournesol résistants à l'attaque de $\mathrm{S}$ sclerotiorum sur bourgeon terminal passe par la sélection de lignées résistantes. Ainsi, on a besoin de méthodes fiables pour mesurer cette résistance applicables tous les ans. Actuellement, l'évaluation des génotypes ne peut être réalisée qu'au champ en infection naturelle. Cette étude rapporte d'autres méthodes en contamination artificielle utilisant aussi bien les ascospores que le mycélium. L'inoculum est apporté soit directement sur le jeune bouton floral, soit sur tige et feuille. Les caractères mesurés sont le pourcentage d'attaque et l'indice d'attaque pour le test ascospore ou la longueur de la nécrose et la vitesse de la progression du champignon pour le test mycélium. L'infection naturelle est prise comme base de comparaison des autres méthodes car les classements variétaux observés au champ sont stables. Dans cette étude, la variété sensible est atteinte à $45 \%$ en moyenne et les variétés résistantes sont sans symptôme. Les lignées femelles montrent des comportements variés mais les parents mâles sont sans symptôme. L'utilisation d'une note, l'indice de sensibilité, n'apporte pas plus de précision dans le classement variétal que le pourcentage des plantes atteintes. Parmi les différentes méthodes faisant appel au test "mycélium", celle mesurant l'extension d'une nécrose à partir de pastilles mycéliennes déposées sur le bourgeon terminal est la mieux corrélée avec l'infection naturelle $(\mathrm{r}=0,554, \mathrm{n}=20)$. Le test "ascospore " pratiqué sur le jeune bouton floral (B8-B12) après une nécrose préalable sur l'une des feuilles l'entourant est aussi corrélé significativement avec l'attaque naturelle. Les réponses obtenues aux tests mycélium sur feuille et tige sont indépendantes de la sensibilité sur bourgeon terminal, ce qui prouve que les généticiens doivent traiter les attaques sur feuille, tige et bourgeon comme s'il s'agissait de maladies distinctes. Le test "mycélium" sur bourgeon, relativement facile à mettre en œuvre, ne nécessite que le dépôt de rondelles de coton hydrophile et peut être intégré dans la sélection pour la résistance du tournesol à l'attaque de $\mathrm{S}$ sclerotiorum sur bourgeon terminal du tournesol.

\section{Sclerotinia sclerotiorum / tournesol / bourgeon terminal / test/corrélations}

\footnotetext{
*Present address: INRA, Laboratoire de Pathologie végétale, CRASMA, BP:S/40 Méknès, Morocco.

** Correspondence and reprints.
} 


\section{INTRODUCTION}

Sclerotinia sclerotiorum (Lib) de Bary can attack most parts of the sunflower plant (Helianthus annuus L). Terminal bud attack was first identified in France in 1980 and is now found frequently (Tourvieille et al, 1992). Since infection can lead to destruction of the terminal bud, and thus of the capitulum, there can be considerable yield loss.

Some satisfactory chemical control has been obtained under experimental conditions (Peres et al, 1991), but present economic and environmental considerations, and the fact that resistance is known in modern cultivated sunflowers, mean that genetic control appears to be of greatest interest. However, the development of resistant varieties makes it necessary to be able to test the reaction of breeding material, parental inbred lines and hybrids.

Breeding tests have been developed for most forms of Sclerotinia attack on sunflowers (Vear and Guillaumin, 1977; Tourvieille and Vear, 1984) but, to date, the only method of evaluating reaction to terminal bud attack is to determine the proportion of plants infected during natural attacks on yield trials (Tourvieille et al, 1992). Such observations give repeatable results, but since natural infection depends on climatic conditions (mild, wet spring, Achbani and Tourvieille, 1993), they can only be made irregularly, according to when and where the disease occurs.

The aim of this study was to compare the reaction of a range of sunflower genotypes to natural attack and to different artificial methods of infection on terminal buds and also on stems and leaves, in order to develop a reliable breeding test.
Infection by $S$ sclerotiorum is the result of 2 succesive phases. The first phase is ascospore germination, which many authors have found to require the presence of either senescing tissue or nutritive substances (Purdy and Bardin, 1953; Mellinger and Hooker, 1969; Natti, 1971). This behaviour has been shown for $S$ sclerotiorum on oilseed-rape (Brun and Renard, 1983) and both for cotyledon (Tourvieille and Vear, 1990) and capitulum (Lamarque et al, 1985, Says-Lesage and Tourvieille, 1988) attack on sunflower. For the latter, infection occurs only on the floral surface, during flowering and during the period when pollen is produced. It is likely that nectar and pollen may provide the sources of energy necessary for spore germination. On the dorsal surface of the capitulum, infection is possible only by Sclerotinia mycelium. The second phase is penetration and invasion of plant tissues. During this phase, the fungus destroys the tissues before invading them.

This information led us to use infections with suspensions of ascospores on terminal buds and young leaves, which had first been slightly wounded. The idea was to provide the spore with both an adequate nutritive support and an easy point of entry. Adequate environmental conditions were provided by automatic irrigation.

\section{MATERIALS AND METHODS}

\section{Sunflower genotypes}

The trials were made on 24 genotypes: 4 female (cytoplasmic male sterile) and 4 male (restorer) inbred lines (table I) and the 16 hybrids obtained from a factorial cross of these lines. They were

Table I. Origins of inbred sunflower lines used as parents of the factorial cross.

\begin{tabular}{|c|c|c|}
\hline Inbred & Origin & Breeder \\
\hline \multicolumn{3}{|l|}{ Females (maintainers) } \\
\hline IF1 & Provided by Prograin Génétique & Private \\
\hline $\mathrm{CC} 40$ & Canadian material (CM 408) & INRA \\
\hline 2603 & Moroccan population & INRA \\
\hline CD & (form of HA89), VNIIMK 8931 & USDA \\
\hline \multicolumn{3}{|l|}{ Males (restorers) } \\
\hline IR1 & Provided by Prograin Génétique & Private \\
\hline IR2 & USDA line RHA 274 & Private \\
\hline RHA 801 & Pool of USDA restorers & USDA \\
\hline PAC1 & USDA line* $H$ petiolaris restorer line & INRA \\
\hline
\end{tabular}


chosen to provide a range of reactions from highly resistant to highly susceptible to terminal bud attack. Three commercial hybrids were used as controls for the observations of natural infection: Vidoc (susceptible); Albena and Eurosol (resistant).

\section{Observations of natural attack}

These were made on a trial in a naturally infected field, without irrigation, in the Cher region in central France. A randomized block design was used, with 4 replications and 30 plants per plot.

Two observations were made on each plot: percentage of plants showing symptoms 3 weeks before flowering (star bud stage); and intensity of attack. This was the mean intensity of attack on the plants with some symptoms in each plot, scored on a 1-7 scale (table II).

\section{Artificial infections}

These trials were carried out under netting cages, with an external automatic irrigation system (Tourvieille et al, 1986). This system buffers daily temperature variations and splits rain or irrigation water droplets into a fine mist favourable for $S$ sclerotiorum infection.

The $S$ sclerotiorum isolate used had been obtained from an infected sunflower terminal bud. It was maintained on a $1.5 \%$ agar medium, containing $1 \%$ malt extract at $23 \pm 1^{\circ} \mathrm{C}$. The explants used for infection, $7 \mathrm{~mm}$ in diameter, were cut from the edge of 2-d-old cultures. Ascospores were obtained by the methods described by Tourvieille et al (1978). The spores were suspended either in distilled water or in $10 \mathrm{~g} / \mathrm{l}$ solutions of carrot or tomato juice.

Table II. Observation scale for natural and artificial infections by $S$ sclerotiorum ascospores on sunflower terminal buds.

\begin{tabular}{cl} 
Note & \multicolumn{1}{c}{ Symptom } \\
\hline 0 & No symptom \\
1 & $\begin{array}{l}\text { Beginning of infection on young leaves or } \\
\text { bracts around the terminal bud }\end{array}$ \\
2 & $\begin{array}{l}\text { Slight attack on leaves or bracts } \\
\text { with lesions up to } 1 \mathrm{~cm}\end{array}$ \\
3 & Lesions reaching stem or terminal bud \\
4 & Bud or stem partly destroyed \\
5 & Terminal bud or stem completely destroyed \\
6 & Terminal bud destroyed and extension of \\
7 & $\begin{array}{l}\text { lesion along more than } 2 \mathrm{~cm} \text { of the stem } \\
\text { tension along stem of more than } 3 \mathrm{~cm}\end{array}$ \\
\hline
\end{tabular}

\section{Mycelium terminal bud test}

A mycelial explant was placed on the centre of the terminal bud, with a slight pressure in order to improve contact with the plant. It was then covered with wet cotton wool, to keep it in place and maintain sufficient humidity for infection. Ten plants per plot were infected. Reaction was measured by the length of lesions along the stem. Two observations were made, the first $20 \mathrm{~d}$ after infection; and a second, $10 \mathrm{~d}$ later. These permitted calculation of the rate of mycelial extension along the stem between the 2 observations.

\section{Mycelium leaf test}

This test was first described by Bertrand and Tourvieille (1986) for measuring phomopsis reactions. A mycelial explant was placed at the extremity of the main vein of a young fully grown leaf and covered with aluminium foil which was stapled in place. Two leaves on each of 5 plants per genotype were infected. Observations of the length of lesions were made $6 \mathrm{~d}$ after infection.

\section{Mycelium stem test}

A mycelial explant was placed on the stem, in its upper third, maintained in place with adhesive tape, and covered with aluminium foil. For each genotype, 10 plants were infected. The lesion length $6 \mathrm{~d}$ after infection was observed, and a second observation $26 \mathrm{~d}$ later gave a measure of mycelial extension rate.

\section{Ascospore terminal bud test}

This consisted of spraying $5 \mathrm{ml}$ of a spore suspension (50000 spores $/ \mathrm{ml}$ ) onto the terminal bud, with a hand sprayer. The test was carried out with or without wounding the young leaves surrounding the terminal bud (by touching them with a hot soldering iron (Express, ref 2107, diameter $1 \mathrm{~mm}$ ). The plants were then covered with greaseproof paper bags for $4 \mathrm{~d}$. The infections were made on 10 plants per genotype at a date when they were between 8 leaves and the star-bud stage. Observations were made 2 weeks later, using the same notations as for natural attack: percentage of plants showing symptoms; and mean intensity of attack of plants with symptoms. Some similar tests were made in the greenhouse using transparent polythene bags to cover the terminal buds.

\section{Statistical analyses}

The software STAT-ITCF was used for a principal component analysis (PCA) (Philippeau, 1986). 
This essentially descriptive multivariate analysis makes it possible to define graphically the similarities and differences between the tests and between the genotype reactions. The individuals were the sunflower genotypes, and the quantitative variables were the observations of the different tests, which had been transformed to give the same weight to each, removing the effect of the different measurement units.

\section{Microscopic observations}

Observations under blue light $(495 \mathrm{~nm})$ epifluorescence were used to determine the viability of the fungus, by the fluorochromatic test of Heslop Harrison et al (1983), usually used for pollen. These observations were made on plants grown both in the greenhouse and in the field during the first $4 \mathrm{~d}$ after infection with ascospore suspensions.

\section{RESULTS}

All data for the inbred lines and experimental hybrids are presented in table III.

\section{Natural Infection}

For the experimental genotypes, between 0 and $39.4 \%$ of plants were infected. The control hybrid Vidoc showed $45.2 \%$ infection, whereas the resistant varieties had only $1 \%$ (Albena) to $4 \%$ (Eurosol) infection. The male parents showed very low levels of infection (mean $0.7 \%$ ), compared with $13.8 \%$ for female parents and $14.9 \%$ for the hybrids. An analysis of variance indicated that genotype

Table III. Reactions of 16 sunflower hybrids and 8 inbred lines to different Sclerotinia tests and to natural attack on terminal buds".

\begin{tabular}{|c|c|c|c|c|c|c|c|c|c|}
\hline \multirow[t]{3}{*}{ Genotypes } & \multicolumn{5}{|c|}{$\begin{array}{c}\text { Mycelium test } \\
\text { Organ }\end{array}$} & \multicolumn{4}{|c|}{$\begin{array}{c}\text { Ascospore test } \\
\text { Nature }\end{array}$} \\
\hline & \multirow{2}{*}{$\begin{array}{l}\text { Leaf } \\
\mathrm{I}(\mathrm{cm})\end{array}$} & \multicolumn{2}{|c|}{ Steam } & \multicolumn{2}{|c|}{ Bud } & \multicolumn{2}{|c|}{ Artificial } & \multicolumn{2}{|c|}{ Natural } \\
\hline & & $\mathrm{I}(\mathrm{cm})$ & $\mathrm{r}(\mathrm{cm} / \mathrm{d})$ & $\mathrm{I}(\mathrm{cm})$ & $\mathrm{r}(\mathrm{cm} / \mathrm{d})$ & $\%$ & Int & $\%$ & Int \\
\hline$|F 1 \times| R 2$ & 5.1 & 74 & 2.2 & 19.4 & 1.6 & 28.3 & 3.0 & 16.6 & 3.2 \\
\hline $\mathrm{CC} 40 \times \mathrm{IR} 2$ & 7.1 & 65.4 & 1.9 & 18.3 & 1.7 & 45.0 & 5.4 & 43.2 & 3.2 \\
\hline $2603 \times$ IR2 & 7.1 & 77.6 & 2.4 & 23.1 & 1.0 & 90.0 & 4.2 & 41.4 & 3.4 \\
\hline $\mathrm{CD} \times \mathrm{IR} 2$ & 8.3 & 35.2 & 0.7 & 12.3 & 1.6 & 57.1 & 3.4 & 23.7 & 2.6 \\
\hline IF1 × RHA801 & 5.9 & 65.2 & 1.7 & 10.0 & 1.0 & 57.1 & 3.0 & 5.2 & 1.3 \\
\hline $\mathrm{CC} 40 \times \mathrm{RHA} 801$ & 7.5 & 61.8 & 1.4 & 15.0 & 1.3 & 45.0 & 6.3 & 29.0 & 2.8 \\
\hline $2603 \times$ RHA801 & 8.5 & 71.4 & 2.1 & 17.3 & 1.0 & 57.1 & 4.7 & 12.5 & 2.3 \\
\hline $\mathrm{CD} \times \mathrm{RHA} 801$ & 7.1 & 61.2 & 1.6 & 12.9 & 0.7 & 50.8 & 2.2 & 7.0 & 0.8 \\
\hline $\mid \mathrm{F} 1 \times \mathrm{IR} 1$ & 6.7 & 54.2 & 1.5 & 15.2 & 0.5 & 45.0 & 5.1 & 0.0 & 0.0 \\
\hline $\mathrm{CC} 40 \times \mathrm{IR} 1$ & 8.9 & 51.2 & 1.4 & 14.1 & 0.6 & 58.3 & 5.3 & 23.2 & 2.9 \\
\hline $2603 \times \mathrm{IR} 1$ & 8.7 & 56.5 & 1.5 & 19.3 & 1.5 & 45.0 & 3.3 & 0.0 & 0.0 \\
\hline $\mathrm{CD} \times \mathbb{I R} 1$ & 9.9 & 64.0 & 1.6 & 11.5 & 0.9 & 38.7 & 5.5 & 11.3 & 0.7 \\
\hline $\mathrm{IF} 1 \times \mathrm{PAC} 1$ & 4.5 & 57.3 & 1.3 & 13.2 & 1.4 & 26.6 & 5.0 & 0.0 & 0.0 \\
\hline $\mathrm{CC} 40 \times \mathrm{PAC} 1$ & 8.8 & 60.8 & 1.5 & 20.6 & 1.8 & 51.3 & 6.6 & 16.9 & 2.0 \\
\hline $2603 \times$ PAC1 & 6.6 & 53.8 & 1.5 & 10.1 & 1.1 & 58.3 & 3.7 & 5.0 & 0.6 \\
\hline $\mathrm{CD} \times \mathrm{PAC} 1$ & 6.1 & 41.4 & 0.7 & 9.6 & 0.7 & 0.0 & 0.0 & 2.7 & 0.5 \\
\hline IF1 & 9.1 & 55.6 & 1.6 & 7.1 & 1.9 & 42.2 & 4.5 & 7.3 & 0.7 \\
\hline $\mathrm{CC} 40$ & 11.2 & 51.7 & 1.3 & 17.6 & 1.8 & 49.6 & 6.4 & 31.0 & 3.1 \\
\hline 2603 & 8.3 & 56.2 & 1.6 & 13.3 & 1.6 & 76.7 & 5.0 & 17.0 & 2.9 \\
\hline$C D$ & 11.7 & 44.0 & 1.1 & 10.1 & 0.8 & 39.2 & 6.0 & 0.0 & 0.0 \\
\hline R1 & 13.4 & 35.0 & 1.0 & 9.9 & 0.6 & 80.0 & 5.8 & 0.0 & 0.0 \\
\hline $\mathrm{R} 2$ & 10.8 & 38.3 & 1.3 & 8.2 & 1.1 & 33.3 & 2.0 & 0.0 & 0.0 \\
\hline RHA801 & 9.6 & 36.0 & 0.8 & 5.3 & 0.1 & 30.0 & 6.5 & 0.0 & 0.0 \\
\hline PAC1 & 4.1 & 34.5 & 1.0 & 4.0 & 0.5 & 0.0 & 1.5 & 5.0 & 0.9 \\
\hline CV $(\%)$ & 41.1 & 14.5 & 29.5 & 33.0 & 37 & 49.7 & 30.4 & 65.1 & 68.2 \\
\hline $\mathrm{F}$ & 4.7 & 12.3 & 5.1 & 10.4 & 11.9 & 2.8 & 3.6 & 10.9 & 7.4 \\
\hline PPDS & 3.0 & 9.9 & 0.9 & 4.3 & 0.4 & 2.4 & 2.8 & 11.7 & 1.3 \\
\hline
\end{tabular}

* $I=$ length of lesions; $r=$ mycelium extension rate; int $=$ intensity of attack 
differences were highly significant, but with quite considerable variation (coefficient of variation $\mathrm{CV}=65.1 \%$ ).

\section{Mycelium bud test}

This test gave a mean of $92 \%$ of plants with symptoms. For a mean length of symptoms of $13.2 \mathrm{~cm}$, extremes were $23.1 \mathrm{~cm}$ $(2603 \times$ IR2) and $4.0 \mathrm{~cm}$ (inbred PAC1). The male parents had lesion lengths that were only half those of the female lines $(6.8$ and $12.0 \mathrm{~cm}$, respectively). The hybrids showed slightly larger symptoms (mean $14.5 \mathrm{~cm}$ ) than the females. Genotypic differences were significant.

\section{Mycelium leaf test}

A total of $99.2 \%$ of leaves were successfully infected. The lesion length varied from $4.1 \mathrm{~cm}$ for PAC1 to $13.4 \mathrm{~cm}$ for IR1. The inbred lines showed larger symptoms than the hybrids (males: $9.5 \mathrm{~cm}$; females: $10.1 \mathrm{~cm}$; hybrids: $7.2 \mathrm{~cm})$. Genotypic differences were significant.

\section{Mycelium stem test}

Infection was successful in all cases. The lesion length was greatest for the hybrid $2603 \times$ IR2 $(77.6 \mathrm{~cm})$ and the same hybrid showed the fastest extension rate $(2.4 \mathrm{~cm} / \mathrm{d})$. The inbred PAC1 appeared the most resistant genotype, with a lesion measuring $3.5 \mathrm{~cm}$ and an extension rate of $0.5 \mathrm{~cm} / \mathrm{d}$. In general, the male parents were less susceptible to this test (mean lesion length: $3.6 \mathrm{~cm}$ ) than the female lines $(5.1 \mathrm{~cm})$ and the hybrids $(5.9 \mathrm{~cm})$. An analysis of variance indicated that genotypic differences were significant.

\section{Ascospore terminal bud test}

In the absence of wounding, no symptoms appeared. In contrast, when infections were made after wounding young leaves, symptoms like those of natural attack appeared. Percentage infection varied between genotypes, from $0 \%$ for several genotypes (table III) to $76 \%$ for the female inbred 2603.
Intensity of attack varied from 4.5 for 2603 to 0 for PAC1 and $C D \times P A C 1$.

In the greenhouse, under favorable conditions for the disease $\left(18^{\circ} \mathrm{C}, \mathrm{RH} 100 \%\right)$, the susceptible genotype $\mathrm{CC} 40$ infected with spores suspended in a tomato juice solution and covered with polythene bags, showed symptoms $5 \mathrm{~d}$ after infection. The young leaves around the terminal bud became yellow-brown at their extremities. Plants of the resistant genotype PAC1, infected in the same way, showed no such symptoms. Light microscopy of the discoloured parts of leaves showed the presence of germinated ascospores with a few hyphae. The fungus was present on the upper $2 / 3$ of the leaf, especially in the centre. The plants under netting cages, covered with greaseproof paper bags showed no symptoms. Under the microscope, a few spores were visible, but their negative colouration with the fluorochromatic test indicated that they were no longer viable. On plants that were not covered with bags, some spores started to germinate and after about $5 \mathrm{~d}$, they were still viable. Microscopic examination of flower bud bracts showed only ungerminated spores.

\section{Principal Component Analysis}

Since the male parents showed no symptoms, an atypical behaviour, possibly due to their relative lack of vigour, they were not included in the PCA.

\section{Correlations between variables}

The 2 measurements of natural infection (\% attack and intensity of attack) were closely related $(r=0.891)$ (table IV). Similarly, for the stem test, the rate of extension and lesion length at the first measurement were closely correlated. However, for the mycelium bud test, extension rate was correlated neither with lesion length nor with natural attack data. The test observations that best correlated with natural attack were lesion length from the mycelium infection on buds and percentage attack after the ascospore infection of terminal buds. Intensity of attack after the ascospore test was correlated only with lesion length after the leaf test, which generally appeared to give results independent of the other tests. 
Table IV. Correlation between the results of different Sclerotinia tests and observation on 16 sunflower hybrids and 4 inbred lines ( $p=0.05$ for $r=0.444 ; p=0.01$ for $r=0.561$ )

\begin{tabular}{lrlllllll}
\hline & $L 1$ & $S 1$ & $S 2$ & $B 1$ & $B 2$ & $A 1$ & $A 2$ & $N 1$ \\
\hline L1 & 1.000 & & & & & & & \\
S1 & -0.306 & 1.000 & & & & & & \\
S2 & -0.173 & 0.943 & 1.000 & & & & & \\
B1 & -0.050 & 0.562 & 0.554 & 1.000 & & & & \\
B2 & 0.108 & 0.316 & 0.069 & 0.230 & 1.000 & & & \\
A1 & 0.233 & 0.221 & 0.462 & 0.360 & 0.082 & 1.000 & & \\
A2 & 0.510 & 0.142 & 0.196 & 0.278 & 0.303 & 0.344 & 1.000 & 1.000 \\
N1 & 0.117 & 0.318 & 0.337 & 0.554 & 0.336 & 0.474 & 0.375 & 0.893 \\
N2 & 0.041 & 0.346 & 0.375 & 0.543 & 0.362 & 0.475 & 0.276 & 0.000 \\
\hline
\end{tabular}

$\mathrm{L} 1$ = length of lesions along the leaf (mycelium leaf test); $\mathrm{S} 1$ = length of lesions along the stem (mycelium stem test); $\mathrm{S} 2$ = mycelium extension rate (mycelium stem test); $\mathrm{B} 1$ = length of lesions along the terminal bud (mycelium bud test); $B 2=$ mycelium extension rate (mycelium terminal bud test); $A 1=$ percentage of plants showing symptoms (ascospores terminal bud test); $\mathrm{A} 2$ = mean intensity of attack on the plants with some symptoms (ascospores terminal bud test); N1 = mean intensity of attack on the plants with some symptons (natural attack); N2 = percentage of plants showing symptoms (natural attack).

\section{Circle of correlations}

The plane $1-2$ represents $63 \%$ of the variation (fig 1). The variables, test observations, best represented are at the exterior of the circle. They are divided into 4 groups: (i) lesion length on leaves (L1); (ii) intensity of attack from the ascospore test (A2) and, perhaps, rate of extension from the mycelium bud test (B2); (iii) natural attack data (N1 and N2), \% attack after the ascospore test (A1) and lesion length from the bud mycelium test (B1); and (iv) mycelium stem test observations (S1 and S2).

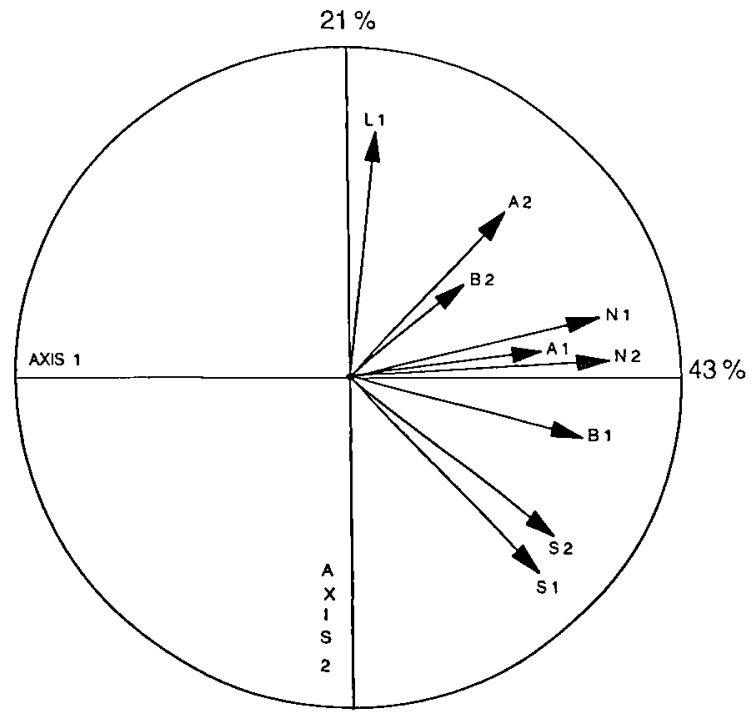

Fig 1. Circle of correlations between the initial variables, results of Sclerotinia infections, and axis 1 (horizontal) and 2 (vertical).
Axis 1 ( $43 \%$ of total inertia) defines natural infection and the reaction to the mycelium bud test; axis $2(21 \%$ of inertia) mainly defines the reaction to the leaf test. Reactions to the leaf and stem tests quite often appear somewhat in opposition, a genotype showing resistance to one test being rather susceptible to the second. In addition, reaction to leaf and bud tests appear to be independent. The tests best related to natural bud attack are those involving early measurements of bud infections.

The graph positioning individual genotypes (fig 2) shows that they are widespread, indicating a satisfactory choice of material for

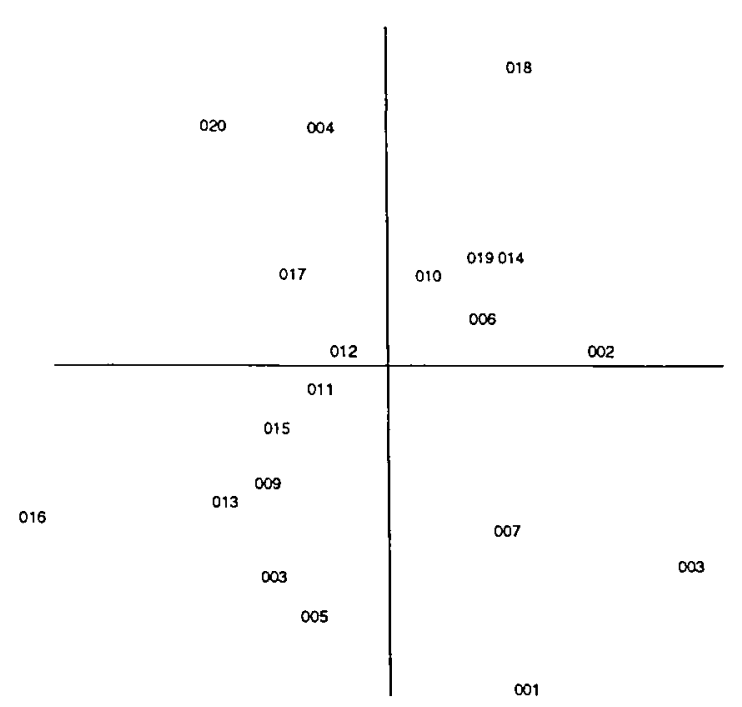

Fig 2. Projection of 20 sunflowers genotypes on the plane formed by axis 1 (horizontal) and 2 (vertical) for Sclerotinia infections. 
this study. Axis 1 discriminates between the genotypes according to bud reaction, the more resistant being towards the left-hand side of the graph and the more susceptible towards the right. On axis 2 , defined by the leaf test reaction, the more resistant genotypes are towards the bottom, the more susceptible towards the top.

\section{DISCUSSION}

Natural attack was taken as a basis to compare the different artificial infection methods. Tourvieille et al (1992) showed that, in contrast to Sclerotinia attack on capitula, the ranking of hybrid genotype reactions to terminal bud attack remained stable in different environmental conditions. In the present trials, the control varieties showed the same reactions as those reported earlier: Vidoc showed $45 \%$ attack; Albena and Eurosol almost no symptoms. However, the heterogeneity of inoculum between different plots could reduce precision. In the present case, the coefficient of variation was quite high (for disease trials) at $65 \%$.

The main problem found in these trials was the complete absence of symptoms for the male inbreds. Some, such as IR2, gave susceptible hybrids and others, such as IR1, were susceptible to artificial ascospore infections. There is thus no evidence that they all carry genes that give complete resistance to terminal bud attack. It is possible that, owing to their small size and lack of vigour, they do not provide a favourable environment for Sclerotinia infection of terminal buds. The results of Castaño et al (1993) for 7 restorer lines are in agreement. These lines were chosen for their variation in reaction to different forms of Sclerotinia attack, and not particularly their terminal bud reactions. Six lines showed no symptoms and one line only $5 \%$ of plants with symptoms. In comparison, female lines had from $0 \%$ attack (including CD) to $23 \%$ attack (for CC40), which is very similar to the present results.

Further trials of inbred lines in particularly favourable conditions for Sclerotinia attack will be necessary to determine if male inbreds can show symptoms, or whether the susceptibility of their hybrids cannot be predicted from their reactions per se in the field, but must be determined from general combining abilities calculated from test hybrids. It is possible that artificial infections would be an improvement over natural attack if they made it possible to predict hybrid reactions from those of the parents.

The semi-saprophytic behaviour of $S$ sclerotiorum frequently described in the literature (Brun and Renard, 1983; Penaud, 1984; Lamarque et al, 1985; Says-Lesage and Tourvieille, 1988) appears to be the rule for artificial terminal bud infection. In the absence of any nutritive substance, the fungus appeared to be incapable of penetrating healthy tissues. Infections with mycelial explants were successful, whereas spores required the presence of necrotic tissue, even when spore germination was facilitated by the use of tomato or carrot juice suspensions.

Humidity seems to be the decisive factor determining successful infection by spores. Polythene bags maintained a saturated atmosphere with the presence of liquid water for the necessary length of time, whereas greaseproof paper bags appeared not to do so. Light is also important; when plants covered with polythene bags were kept in a growth chamber with only half the normal light intensity, the infections were not successful. A saturated atmosphere, liquid water and light were also the limiting factors reported by Lamarque et al (1985) for capitulum infections. It is probably the combination of liquid water and a nutritive supply that permits the fungus to produce a sufficient mass of mycelium to secrete the enzymes necessary to kill and colonize host tissues.

The significant correlation between results of the mycelium bud test and the stem test agree with those of Castaño et al (1993), who studied 4 lines (CC40, 2603, CD, PAC1) common to our trial and 16 different ones. The relationship is not surprising since the measurement of the lesion of the mycelium bud test includes mycelial extension along the stem.

The lack of any significant correlation between results of mycelium tests on leaves and stems with natural or artificial ascospore attacks on terminal buds agrees with the hypothesis of Castaño et al (1993) that the resistances to ascospore penetration and mycelium extension are quite different. The closer relation between natural attack and the mycelium bud test in the present results may be due to the better choice of genotypes for 
this particular study, and also to the different method of scoring.

Since measurements of the intensity of natural terminal bud attack are closely correlated with the percentages of plants attacked, it may be proposed that the latter should be preferred, since it is easier to observe and more objective.

The test observations most closely related to percentage natural attack were percentage infection by the ascospore test and length of lesion from the mycelium bud test. However, although correlations were significant, neither were very close $(r=0.474$ and 0.554 , respectively, giving determinations of 22 and $31 \%)$. Levels of artificial attack are much higher than for natural attack and generally have a smaller range, and it may thus be suggested that the wounds made before infection destroyed some forms of resistance of some sunflower genotypes to Sclerotinia entry. Further studies are necessary to determine how to produce ascospore infections of terminal buds without wounds of any size, closely imitating natural attack.

The highly significant correlation between percentage natural attack and lesion length from the mycelium bud test shows that appearance of natural symptoms depends not only on ascospore penetration, but also on the possibilities of mycelial growth in the young leaves, bud and stem. The correlation might be improved further if the mycelial lesions were measured at an earlier stage, corresponding to shorter extension along the stem. At present, since this test is the best correlated with natural terminal bud attack, it ought to be further investigated, for example, to determine its possible general use on inbred lines. This would be comparable with the use of mycelium tests for measuring capitulum resistance on inbred lines and breeding material (Vear and Tourvieille, 1984) followed by observations of semi-natural attack on hybrids.

In conclusion, it thus appears that Sclerotinia attack on sunflower terminal buds shows considerable differences from other forms of infection. Under natural conditions, genotype reactions show clearer resistance or susceptibility, but reproduction of natural attack is more difficult. Further studies on test procedures using ascospores are necessary but since reactions to a mycelium test on the terminal bud show significant correlations with those of natural attack, and this test is quite easy to carry out, it may be proposed for immediate use in sunflower resistance breeding programmes.

\section{ACKNOWLEDGMENTS}

The first author was supported by a doctoral studentship from the French Ministry of Foreign Affairs, as part of a cooperation programme between INRA, France and INRA, Morocco. We would like to thank the CETIOM and PROMOSOL for their general support of this programme.

\section{REFERENCES}

Achbani EH, Tourvieille D (1993) Le tournesol, revue bibliographique de certaines de ses maladies cryptogamiques. Partie 1: La Pourriture blanche. Alawamia 75, 129-154

Bertrand F, Tourvieille D (1986) Phomopsis du tournesol: Test de sélection. Inf Tech CETIOM $98,12-18$

Brun H, Renard M (1983) Sclerotinia sclerotiorum sur colza: techniques de contamination. agronomie 3,93

Castaño F, Vear F, Tourvieille D (1993) Resistance of sunflower inbred lines to different forms of attack by Sclerotinia sclerotiorum and relations with some morphological characters. Euphytica 68, 85-98

Heslop-Harrison J, Heslop-Harrison Y, Shivanna KR (1983) Fluorochromatic stain. Theor Appl Genet 67, 367-375

Lamarque $C$, Leconte $M$, Berrier J, Jaunet $A$ (1985) Recherche de sites de contamination du capitule de tournesol par les ascospores de Sclerotinia sclerotiorum (Lib) de Bary. Inf Tech CETIOM Chapter 2 92, 27-35

Mellinger HC, Hooker WJ (1969) Aspect of Sclerotinia sclerotiorum infection of sebago potato. Am Potato J 46, 432-433

Natti JJ (1971) Epidemiology and control of bean white mould. Phytopathology 61, 669-674

Penaud A (1984) Les pétales et la contamination du colza par Sclerotinia sclerotiorum. Inf Tech CETIOM 89, 20-28

Perez A, Allard LM, Regnault Y (1991) Sclerotinia sclerotiorum du bourgeon terminal du tournesol: Étude de la protection fongicide. ANPP $3^{\text {eme }}$ Conf Int sur les Maladies des Plantes, Bordeaux, 3-5 December, 401-405

Philippeau G (1986) Comment interpréter les résultats d'une analyse en composantes princi- 
pales. Service des études statistiques, Ed ITCF, pp 63

Purdy L, Bardin R (1953) Mode of infection to tomato plants by ascospores of Sclerotinia sclerotiorum. Plant Dis Rep 37, 361-362

Says-Lesage V, Tourvieille D (1988) Recherche des sites de pollution et d'infection des fleurons de tournesol, in situ, par les spores de Sclerotinia sclerotiorum. Inf Tech CETIOM 102, 3-13

Tourvieille D, Guillaumin J, Vear F, Lamarque $C$ (1978) Rôle des ascospores dans l'infection du tournesol par Sclerotinia sclerotiorum (Lib) de Bary. Ann Phytopathol 10, 417-434

Tourvieille D, Vear F (1984) Comparaison de méthodes d'estimation de la résistance du tournesol au Sclerotinia sclerotiorum (Lib) de Bary. agronomie 4, 517-525

Tourvieille D, Vear F, Habouzit J (1986) Culture du tournesol sous tunnel en filet avec humec- tation contrôlée pour l'étude de Sclerotinia sclerotiorum. Inf Tech CETIOM 96, 20-28

Tourvieille D, Vear F (1990) Heredity of resistance to Sclerotinia sclerotiorum in sunflowers. III: Study of reaction to artificial infections of roots and cotyledons. agronomie 10, 323-330

Tourvieille D, Vear F, Achbani EH (1992) Attack of sunflower terminal buds by Sclerotinia sclerotiorum, symptoms and resistance. 13th Int Sunflower Conf, 8-10 September, Pisa, Italy, 859-864

Vear F, Guillaumin J (1977) Étude des méthodes d'inoculation du tournesol par Sclerotinia sclerotiorum et application à la sélection. Ann Amélior Plantes 27, 523-531

Vear F, Tourvieille D (1984) Recurrent selection for resistance to Sclerotinia sclerotiorum in sunflowers using artificial infections. agronomie 4, 789-794 